\begin{tabular}{|c|c|c|c|c|}
\hline $\begin{array}{l}\text { Marginal } \\
\text { spines. }\end{array}$ & $\begin{array}{c}\text { Large sp } \\
\text { lateral }\end{array}$ & & & $\begin{array}{l}\text { all spines } \\
\text { f same. }\end{array}$ \\
\hline 28 long & 80 & - & - & $3^{2}$ \\
\hline 36 ، & 66 & • & - & 66 \\
\hline $32 " 6$ & 66 & • & • & 28 \\
\hline $40 "$ & 66 & - & • & 40 \\
\hline 326 & 66 & - & . & 40 \\
\hline
\end{tabular}

The scales on white thorn were found August 18, 1898, upon the large branches. Those on Spiraea, June $\mathbf{1}_{5}, \mathbf{1} 897$, upon the trunk and limbs. The scales on Coliseum ivy, Sept. 30, I 899. Those in the woods, June 16 , 1899 , on the large branches, on dogwood, June ro, r 898 , were on the trunk, on maple at Chicago, Ill., August ro, I900, and those on meadow sweet, June 25,1897 , on all parts of this small plant. It cannot be said that these forms are only occasional, or at all local, neither that they are found on a particular plant, and in such a position as not to get a full supply of nourishment; moreover I do not re- member that the years in which they were found were exceptional. For convenience and also for future reference, I have prepared a separate table of these small forms marked, B. The characters to be observed in the determination of the species are:

Antennae 8-jointed, 3 and 4 longest: 5 always longer than 6 or 7 (the length of the fifth joint is very important) which are variable in length, although often equal and always the shortest. The short spine-like hairs of the first joint normally three, but often only two will be seen. The short spinelike hairs on the outer margin in front of the large blunt spines are also present with the long thin hairs between the antennae, and above the anal plates. The color and size of the scales counts for nothing, as there is every gradation in color from a light redbrown to almost clear black. And it should be said that the length of the first joint is only approximative, as in only a few instances can a specimen be mounted that will show this joint perfectly.

\title{
LIFE HISTORIES OF NORTH AMERICAN GEOMETRIDAE.--XXII.
}

\author{
BY HARRISON G. DYAR, WASHINGTON, D. C.
}

Sciagraphia heliothidata Guenée. According to Dr. Hulst this species has the following synonymy: ocellinata Guen., restorata Walk., subcolumbata Walk., duplicata Pack. The larva has not been previously described.

Egg. Elliptical, well flattened above and below, one end slightly depressed, the other rounded truncate and a little swollen. Shining dark grass-green, almost olive color. Densely, finely reticulate, the cell areas concave, and, on the micropylar end, becoming large and strongly concave, look like the markings on a thimble, which is the cause of this end looking swollen. Size $.6 \times .4 \times \cdot 3$ $\mathrm{mm}$. Later turned dull dark red with central dark green nucleus. Hatched in five days.

Stage I. Head rounded, slightly bilobed, brownish luteous, ocelli black; held obliquely erect; width about $.3 \mathrm{~mm}$. Body moderate or rather thick, the incisures distinct ; feet normal, pale. Uniformly sordid velvety olivaceous tinted, the tubercles rather large, slightly elevated, dusky. obscure. Dorsum and venter shaded, somewhat darker than the sides; no marks ex- 
cept a faintly traced brownish subdorsal line. Setae short, dark. Later became sordid green from the food, with faint traces of narrow brown line on dorsum and a subdorsal line, which widens into a spot on joint 6 .

Stage II. Head slightly bilobed, higher than wide, erect, free; dull luteous greenish, ocelli black; width about $.5 \mathrm{~mm}$. Body moderate, the central segments not much elongated; tubercles rounded and slightly elevated, concolorous; setae short, dark. Translucent yellowish, food green, very finely brown dotted, the dots forming obscurely many longitudinal lines. A large brown spot laterally on joint 6 . The brown is heavier ventrally, forming a distinct shade, likewise divided into ill-formed lines. Feet normal, the anal pair triangular, not exceeded by the anal plate, immaculate.

Stage III. Head rounded, slightly bilobed, flattened before, higher than joint 2 , but held obliquely; pale luteous, faintly brownish mottled, whitish on the eyes and margin of cheeks; width $.75 \mathrm{~mm}$. Body moderate, cylindrical, smooth, the incisures folded. Tubercles obsolete, but the setae rather long, black, all distinctly visible, i to viii ; ia to iib of thorax evenly separated; pointed and black, both on head and body. Green, mostly by transparency, seen without a lens marked only by the large brown spot on joint 6, which rests on top of the spiracle; with a lens very faintly longitudinally whitish lined, the lines separated by pale brownish dottings, heavier ventrally. Abdominal feet concolorous; thoracic ones blackish shaded. The white lines are dorsal, subdorsal, lateral, stigmatal, subventral and ventral, the two latter the most obscure.

Stage IV. Head rounded, slightly bilobed, clypeus a little depressed, free, oblique; green, faintly purplish mottled; width I I mm. Body moderate, segments slightly moniliform, a little roughened by the distinct, concolorous tubercles. Setae rather long, black. Green, obscurely dotted-lined with white in dorsal, subdorsal, lateral, suprastigmatal lines; tracheal line yellowish; following this a subventral line, all alike, narrow. A dark brown spot edged with clouded paler brown above the spiracle on joint 6. Thoracic feet, brown dotted. Shields concolorous, not cornified, weakly lined. Incisures of joints 5 to 9 folded, whitish.

Stage $V$. Head rounded, held obliquely flat, clypeus slightly elevated, paraclypeal pieces not reaching the vertex; green, mottled and streaked with white, tips of mouth parts slightly brownish; width 17 . mm. Body moderate, normal, anal feet triangular with small posterior point bearing a seta shorter than the subanal prongs. Tubercles small, setae distinct, brown. Body green, a dark green dorsal band with central broken white line; subdorsal band broad, greenish white, obscurely dotted and triplicate. Two faint broken whitish lines above the spiracle, one on stigmatal fold, two in subventral space, with traces of still paler ones between the latter and as medioventral line; all obscure and broken into dots. A brown patch above the spiracle on joint 6. Spiracles pale ocherous. Thoracic feet of joint ro shaded with vinous. No discolorous shields. Central incisures folded, yellowish.

Pupa in the earth, shining brown, not peculiar.

Food plant locust (Robinia pseudacacia). Larvae from Washington, D. C.; eggs June 20, mature larvae July 8.

\section{A. SMITH \& SONS, 146-148 WILLIAM ST., New York. GOODS FOR ENTOMOLOGISTS, Klaeger and Carlsbad Insect Pins, Setting Boards, Folding Nets, Locality and Special Labels, Forceps, Sheet Cork, Etc. Other articles are being added, Send for List.}



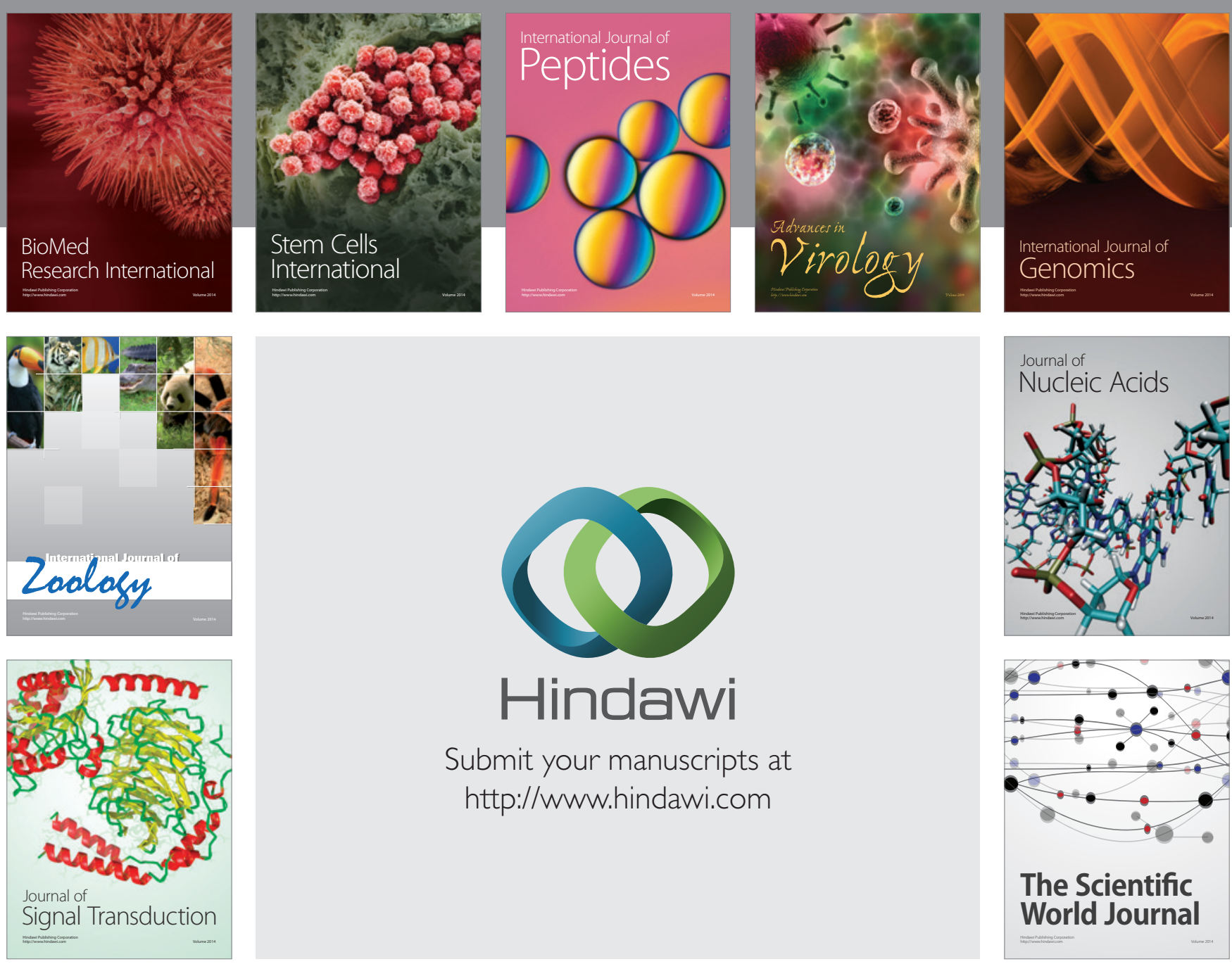

Submit your manuscripts at

http://www.hindawi.com
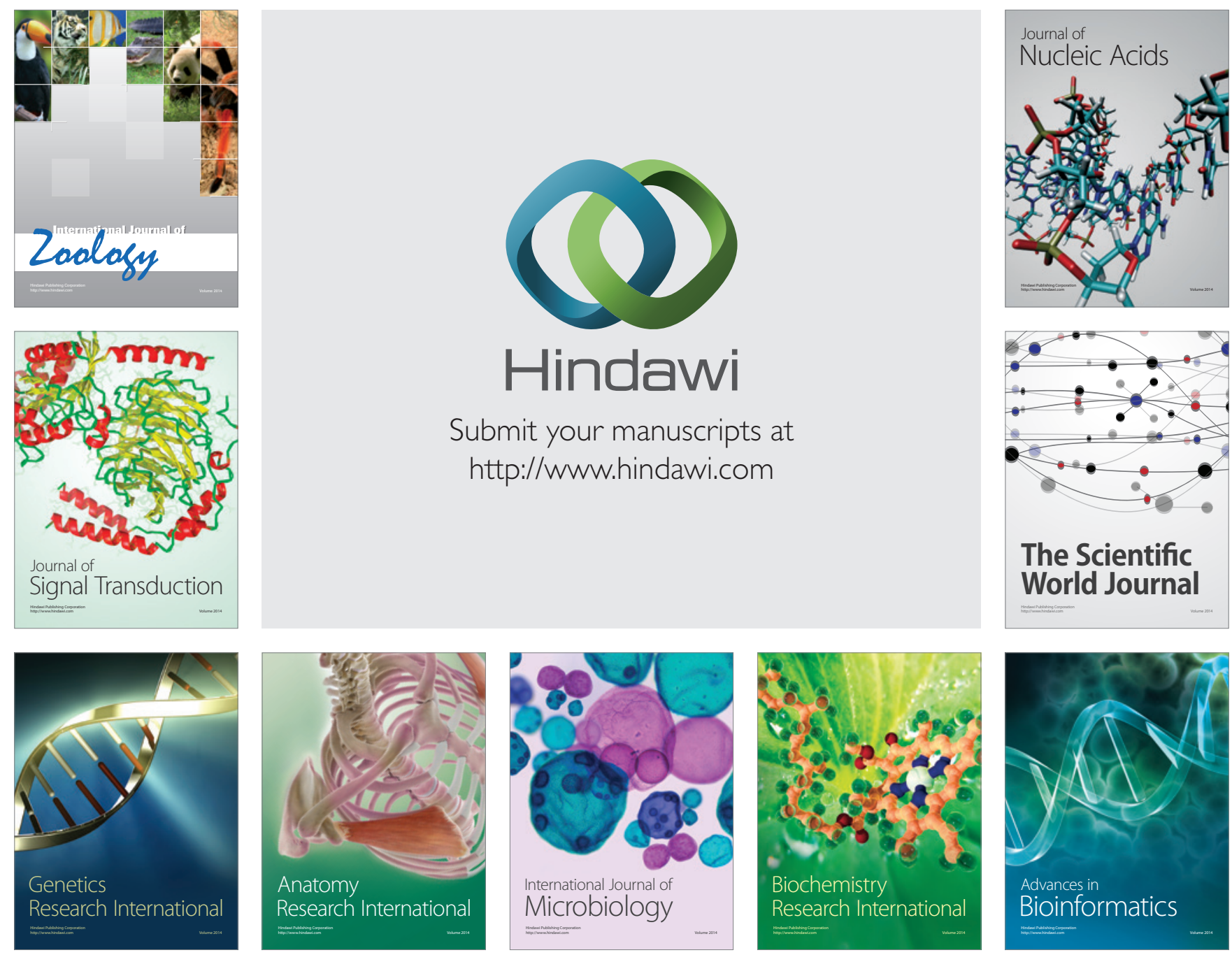

The Scientific World Journal
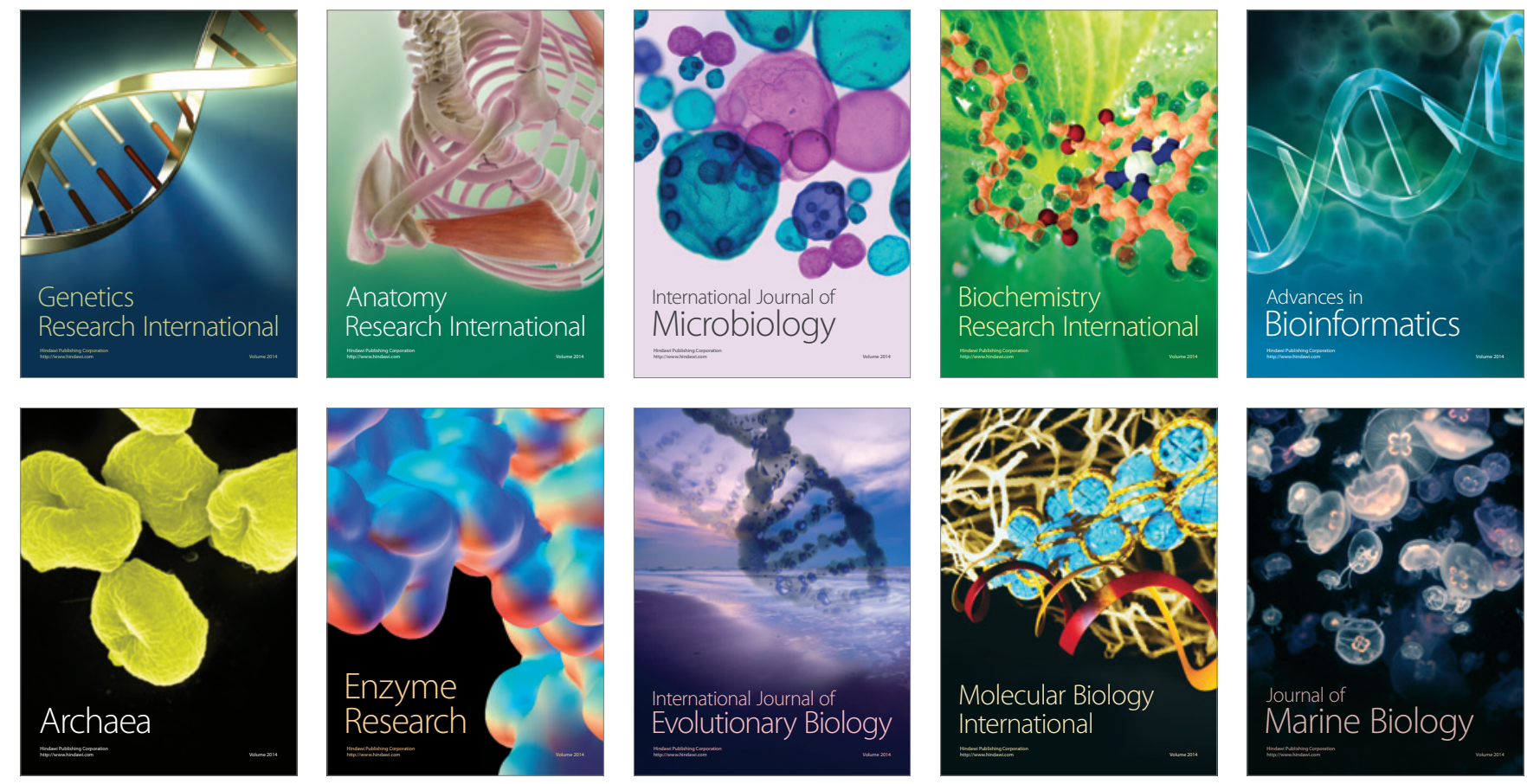